Anthony MEREDITH SJ

(London, Heythrop College)

\title{
COHERENCE AND DISCONTINUITY IN GREGORY OF NYSSA
}

Style apart it is not too hard, despite the evident difficulty in dating some of his writings, to isolate a certain coherence in his writing. This is above all clear in the influence exercised on his «spiritual writings» by the idea of infinity, which he had articulated, partly at any rate, with the aim of meeting the challenge presented by the heretical views of Aetius and Eunomius. The dogmatic usefulness of the idea of of incomprehensibility and infinity, worked out in Contra Eunomium and bore fruit above all in the Life of Moses, where the ultimate revelation of God is of his total transcendence and infinity leading to

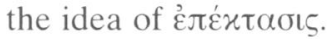

True though this is, it is not the whole story. It seems to be the case that the relatively early De virginitate has no trace of the idea of divine infinity, prominent, in both the Life of Moses and in his 15 Homilies on the Song of Songs. This difference may be due to the differing categories of the writings in question, it is when we come to some of his more deliberately dogmatic works, that the incoherence or differences in expression are or seem to be more detectable. So, is Gregory's account of the divine nature in the Contra Eunomium echoed in his great Catechetical Oration? Again does Gregory present a coherent Christology from Contra Eunomium ${ }^{1}$ to Adversus Apollinarium? Is he divisive in both or unified in both? Is it the case that his theological positions are articulated in response to differing challenges, rather than being the product of a worked out systematic approach?

The former hardly needs much illustration. It has been dealt with often enough and few would dispute it. Several passages from the Contra Eunomium make the point, though it may be the case that the idea of the divine infinity need not be treated despite the learned monograph of Ekkehard Muhlenberg as a Gregorian ,invention”. What is interesting is that a position arrived at least partly, if not entirely, for controversial grounds, should have become the inspiration for Gregory's major spiritual writings, including, to some extent,

\footnotetext{
${ }^{1}$ Cfr. Contra Eunomium III 3.
} 
his more overtly popular sermons like above all Homily 6 on the Beatitudes, though even there the actual word áó@totos does not occur, though ảó@otos

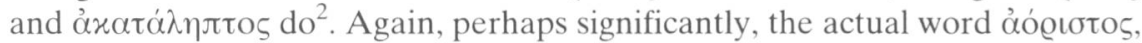
as applied to God occurs nowhere in Gregory's eight Homilies on Ecciesiastes any more than does $\dot{\alpha} x \alpha \tau \alpha \dot{\lambda} \eta \pi \tau o s$. The consensus, however, of scholarly opinion, as represented by both G. May and J. Daniélou dates this series of homilies to 381 or thereabouts, therefore to exactly the same period as that which saw the production of the Contra Eunomium ${ }^{3}$. Perhaps this is why Francoise Vinel in the introduction to her 1990 Sources Chrétiennes 416 edition ${ }^{4}$ locates the work in 378/379 some time before the council of Constantinople of 381, in the course of which Jerome heard Gregory read extracts of his work, a fact he records in his De viris illustribus ${ }^{5}$.

Two or perhaps three possibilities emerge. On the one hand it is could be argued that Gregory's thought on the question of the divine nature is influenced by the chronological sequence of his writing. It could also be urged that the genre of the work in question accounts for variations in both language and theology. Finally, Gregory has no basic theological standpoint, which means that the coherence his writing possesses is more rhetorical and stylistic than theological in the strict sense.

A further area in which a certain tension may be detected in Gregory's approach is in his attitude to the body. On the one hand he stresses the vital part the body has to play in whole structure of the human being. On the other he also insists on the vulnerability of the soul and its being pulled down by the dragging wait of the body $\dot{\varepsilon} \phi o ́ \lambda x เ v$ is the word he often uses as at Catechetical Oration ${ }^{6}$. And yet despite this somewhat negative attitude to the body, which Gregory probably owed to Platonic influence, he is equally insistent on the importance of the sacraments, above al that of the Eucharist, as the divinely inspired way in which we are to be brought to God. This is emphasized in chapter 37 of the same treatise. So he can speak of the transformation ( $\mu \varepsilon \tau \alpha \pi$ óı $\sigma \iota \varsigma)$ of our bodies into his through holy communion ${ }^{7}$.

There seems to be a tension or a fault line between Gregory's insistence on the one hand upon the indestructible character of human freedom, as the likeness of God in us, as at Oratio catechetica 5 and on the other a Neoplatonic

${ }^{2}$ Cfr. Oratio VI de beatitudinibus, ed. J.F. Callahan, GNO VII/2, 140, 27.

${ }^{3}$ Cfr. J. Daniélou, Die Chronologie des oeuvres de Grégoire de Nysse, StPatr 7 (1966) 159-169; G. May, Die Chronologie des Lebens und der Werke dem Gregor von Nyssa, w: Écriture et culture philosophique dans la pensée de Grégoire de Nysse. Actes du Colloque (Chevetogne, 22-26 IX 1969), éd. M. Harl, Leiden 1971, 56-57.

${ }^{4}$ Cfr. Grégoire de Nysse, Homélies sur l'Ecclésiaste, éd. F. Vinel, SCh 416, Paris 1996, 16-20.

${ }^{5}$ Cfr. Hieronymus, De viris illustribus 128, PL 23, 713B.

${ }^{6}$ Cfr. Oratio catechetica magna 10, ed. J.H. Srawley, GNO III/4, 38, 18.

${ }^{7}$ Cfr. ibidem 37, GNO III/4, 96, 21. 
insistence on the unreality of evil and the ultimate necessary disappearance of evil and the consequent salvation of all in the universal apokatastasis. According to Gregory at Oratio catechetica 26 even the devil will be saved and a like view is expressed at Life of Moses ${ }^{8}$. A like view finds expression in Gregory's homily on I Corinthians $15,24-28$. abbreviated to In illud: especially $14,1^{9}$. Is it possible to reconcile these two position? Even if evil does require purification, which is strange if it is non existent, does that mean that we lose the freedom to reject the will of God?

But perhaps the biggest difficulty in Gregory lies in his approach - to the nature of the unity in Christ of the humanity and divinity. Was he more unitary and did he therefore belong to the so-called Logos-sarx school or was he more divisive and therefore closer to the logos-anthropos - word man approach or alternatively was indecisive in the matter. Scholarly opinion on this subject is itself divided, so it will be best to set out the basic evidence from his own writings and see if they point in a particular direction.

The following are the main passages, roughly in chronological order, where Gregory raises the issue of the relation of divine and human in Christ: 1). Contra Eunomium written about $382 / 383^{10}, 2$ ). Ad Theophilum written about 385 or later $\left.^{11}, 3\right)$. Adversus Apollinarium, perhaps a little later and following ${ }^{12}$ (in section 25 we see Gregory's two stage Christology, before and after the resurrection), 4). Oratio catechetica ${ }^{13}$ of about 385 where Gregory, like Origen

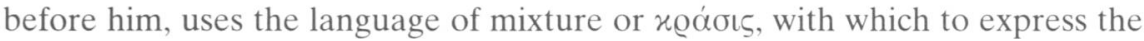
union of divine and human in Christ, 5). finally there is letter 3 of uncertain date addressed to three ladies, Eustathia, Ambrosia and Basilissa, especially sections 15 and following, in which Gregory can be interpreted as defending himself against the charge of being a disciple of Apolinarius.

Ad 1). Contra Eunomium III 3 is in the first instance devoted to a defence of his brother Basil's exegesis of Acts 2, 36, „God has made him [that is Jesus] both Lord and Christ". Basil, in his own Contra Eunomium II 3 had dealt with the text and had applied it to the economy of salvation and not to the theology of the father/Son. In other words Basil had argued that the text applied not to the divinity of Christ but to his manhood. Gregory repeats in full, both Basil's position and also Eunomius reply in his Contra Eunomium III 3, 15-25. This approach, Eunomius argued, ted straight to a division of Christ into two distinct persons, so creating two Christs and two Lords. It is precisely this whole approach, largely endorsed, though importantly modified, which has led Gre-

\footnotetext{
${ }^{8}$ Cfr. De vita Moysis II 82, SCh 1bis/ 54-55.

9 Cfr. In illud: „Quando sibi subiecerit omnia” (1Cor 15, 28), PG 44, 1304-1325.

${ }^{10}$ Cfr. Contra Eunomium III 3, GNO II, 8-9.

${ }^{11}$ Cfr. Ad Theophilum adversus Apollinaristas 5, GNO III/1, 124, 21 - 125, 10.

12 Cfr. Adversus Apollinarium 23, GNO III/1, 164, 13-15.

${ }^{13}$ Cfr. Oratio catechetica magna 10-11, GNO III/4, 38-39.
} 
gory to be accused of being a dyophysite - a view supported by the fact that Theodoret of Cyrrhus in his anti Monophysite Eranistes of about 458 or earlier to cite two passages from Gregory Contra Eunomium III 3, 43 and 64.

However, despite the strongly divisive language of the above two passages the initial impression this created is distinctly modified by the Stoic language of

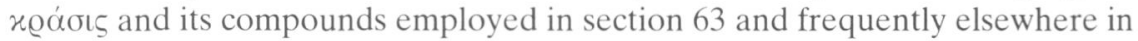
Gregory, though without, as he insists at page 130, line 16 any fusion or

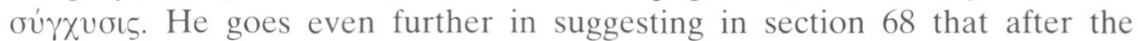
resurrection the risen body of Christ will be absorbed in to the divinity of Christ, like a drop of vinegar in the ocean, Gregory clearly favoured this image with which to articulate his understanding of the post resurrection condition of the union of divine and human.

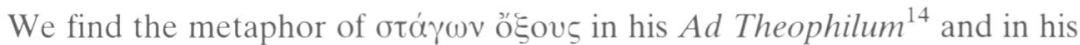
Adversus Apollinarium ${ }^{15}$. Rather than conclude that Gregory is employing two incompatible models with which to articulate his understanding of the nature of the union of divine and human in Christ, it seems better to assume that he is working with a two stage Christology, before and after the resurrection. In postulating a two stage process he is not unlike Origen, who at De principiis ${ }^{16}$ seems to assume a gradual fusion of divine and human in Christ, which he likens to iron [= the humanity of Christ] in the fire, which is clearly the dominant

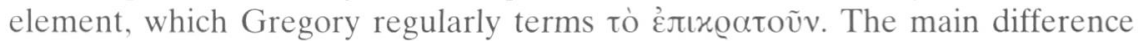
between the two seems to be that for Origen this fusion occurs during Christ's earthly existence, while for Gregory it is reserved for the future life.

Ad 2) Even if it is possible to exonerate Gregory from the charge of inconsistency in his Contra Eunomium, we find in his Ad Theophilum of a few years later and in Letter 3 evidence of the fact that he was vulnerable to the charge of going too far in the direction of Apolinarius Gregory is evidently replying to the charge of splitting Christ into two. There he argues in a passage used by the Monophysite Eutychians: „If the mortal in the immortal becomes itself immortal and if the corruptible becomes incorruptible and in like manner were transformed ( $\mu \varepsilon \tau \varepsilon \pi \circ เ \eta \dot{\theta} \eta)$ what ground if left for those who assert that we divide what is one into twofold distinction". It is hardly surprising that the strong emphasis on the unity of Christ prior to the resurrection in this passage was popular with later Monophysites. It also illustrates the difficulties experienced by modern scholars in their attempts to categorise Gregory's Christology.

Ad 3) In the much lengthier treatise Adversus Apollinarium, probably of a slightly later date, Gregory is anxious to distinguish his position from that of

${ }^{14}$ Cfr. Ad Theophilum 8, GNO III/1, 126, 19.

${ }^{5}$ Cfr. Adversus Apollinarium 42, GNO III/1, 201, 10.

${ }^{16}$ Cfr. Origenes, De principiis II 2, 4-7, SCh 252, 246-248. 
Apolinarius, with whom Basil had arguably conducted a correspondence ${ }^{17}$. In the course of his refutation of Apolinarius, whose views he was subsequently accused of harbouring, Gregory insists in his treatise ${ }^{18}$ that his adversary by depriving Christ of a human mind, had succeeded in turning Christ into an animal a $x \tau \tilde{\eta}$ vos. One of the arguments of Apolinarius had been that the necessarily sinful character of human nature meant that the sinless Christ could not have assumed a human mind. To this Gregory rather surprisingly replies in section 26 that the Word took upon himself our human filth (@úros) and in so doing purified and restored it That this was the view of Gregory receives further support ${ }^{19}$, where he states that in his patience the Word took upon him self our fallen human nature, though whether individual or corporate is not quite clear. Even so the general picture is clear. Christ was composed of a divine and human nature, which were distinct from each other.

Ad 4). The generally dyophysite reading of Gregory receives further support from the Christology of the Oratio catechetica. The Stoic language of

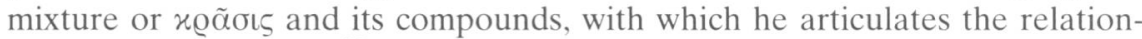
ship of body and soul ${ }^{20}$ is also frequently employed to define/describe the relation of divinity and humanity in Christ $^{21}$. There is one expression, however, which occurs on at least four separate occasions in the treatise which has divisive implications. The humanity of Christ is stated to be God receiving $\theta$ codó ${ }_{0 \varsigma^{22}}$, whereas in chapter 37 the same word occurs three times ${ }^{23}$ but on each occasion it is not the manhood that receives the deity, but the body

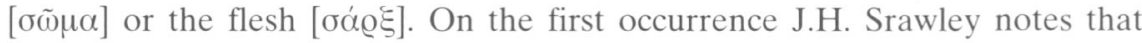
Gregory's language is careless. It was cited like passage above referred to from Contra Eunomium III 3 by Theodoret in his Eranistes. But the other passages point in a quite different and more unitary direction. Did Gregory have a coherent position or has modern interpreters justified in the reserve they have for Christology?

Ad 5) Letter 3 is of uncertain date and purpose. It is easy to read it as Gregory's defence of his position against the charge of being a follower of Apolinarius. Yet there are certain passages in it that seem decidedly monophysite in tone. The editor of the Sources Chrétiennes edition of the letters does not think the letter displays Gregory as being on the defensive against charges of being a follower or fellow traveller of Apolinarius. However, in section 15 we find Gregory insisting on the presence in both body and soul of the light of

17 Cfr. Basilius, Epistolae 261-264.

18 Cfr. Adversus Apollinarium 23, GNO III/1, 165, 26.

${ }^{19}$ Cfr. ibidem 53, GNO III/1, 221, 17-19.

${ }^{20}$ Cfr. Oratio catechetica magna 6, GNO III/4, 22, 8 .

${ }^{21}$ Cfr. ibidem 11 and 16, GNO III/ 4, 39, 21 and 48, 7.

22 Cfr. ibidem 32, GNO III/4, 78, 10.

${ }^{23}$ Cfr. ibidem 37, GNO III/4, 94, 9; 96, 16; 97, 21 
the deity which transforms it into something purer and better ${ }^{24}$. The language of mixture recurs in section 22. Yet in section 24 he addresses those who accuse him of describing Mary as bearer of man rather than as $\Theta \varepsilon$ cotó $^{25} \varsigma^{25}$. If the passage means what it appears to mean $\alpha \dot{v} \theta \varrho \omega \pi$ ó seems to dismiss, despite the fact that he may have been accused of using it himself. So yet again the question arises on what side of the divide does Gregory belong? His ambiguity is palpable. In many ways like Athanasius before him he wanted to insist on the divine action in Christ as deifying, yet when it came to certain difficult passages his resource was to adopt a dyophysite strategy. Hence the permanent ambiguity in his writings.

$* * *$

It probably seems ungracious and ungrateful to endeavour to uncover unclarities or inconsistencies in a long dead and great writer. My motive has been in all this to try by means of exploring and perhaps exposing fault lines in Gregory's treatment of certain important areas to come in this way to a better appreciation of his contribution to the history of Christian thought. All great writers have in them built in incoherences or inconsistencies, To grasp and perhaps wrestle with them is a way into their thought. If evil is unreal why do we need redemption from it? If we are bound top be saved what is the point of effort? If the body is an unwanted burden, why do we need to keep it at all? Finally if God is totally beyond the reach of our minds, why discuss the fittingness or otherwise of his redemption of the world through Christ? Gregory is wrestling as are all serious Christians with profound mysteries, we should be grateful to him for forcing us to explore them with him.

\footnotetext{
${ }^{24}$ Cfr. Epistula 3, 15, SCh 363, 134.

25 Cfr. ibidem 22 and 24, SCh 363, 140 and 142-144.
} 